\title{
Peripherally Inserted Central Catheter dan Pemberian Terapi Intravena pada Neonatus
}

\author{
Yani Setiasih, Sari Fatimah, Siti Yuyun Rahayu Fitri \\ Fakultas Keperawatan Universitas Padjadjaran \\ E-mail:yuyun_rahayu71@yahoo.com
}

\begin{abstract}
Abstrak
Penelitian sebelumnya menemukan bahwa Peripherally Inserted Central Catheter (PICC) efektif dalam pemberian terapi intravena. Belum banyak penelitian yang membandingkan pemberian terapi intravena antara akses intravena yang biasa dilakukan saat ini. Penelitian ini bertujuan membandingkan antara akses intravena perifer dengan Peripherally Inserted Central Catheter (PICC) terhadap efektivitas pemberian terapi intravena pada neonatus. Jenis penelitian ini adalah deskriptif komparatif. Dengan teknik purposive sampling, 32 neonatus diikutsertakan sebagai subjek yang terbagi menjadi dua kelompok yaitu kelompok dengan akses intravena perifer dengan PICC. Pada kelompok dengan akses intravena perifer $(\mathrm{n}=16)$ dan pada kelompok dengan PICC $(\mathrm{n}=16)$. Efektivitas akses intravena dinilai dari kesesuaian terapi intravena yang didapat neonatus dengan kebutuhan yang seharusnya selama 24 jam dalam waktu lima hari menggunakan lembar observasi. Data dianalisis menggunakan uji fisher exact. Hasil penelitian menunjukkan bahwa pemberian terapi intravena menggunakan PICC lebih efektif dibandingkan pemberian terapi intravena menggunakan akses intravena perifer $(\rho=0.00)$. Perawatan neonatus yang membutuhkan terapi intravena di rumah sakit lebih disarankan menggunakan PICC dibandingkan dengan akses intravena perifer.
\end{abstract}

Kata kunci: Akses intravena perifer, neonatus, Peripherally Inserted Central Catheter (PICC), terapi intravena.

\section{Peripherally Intravenous with Peripherally Inserted Central Catheter Access and The Effectiveness of Intravenous Therapy in Neonates}

\begin{abstract}
Previous studies have found that peripherally inserted central catheter (PICC) is effective for delivering an intravenous therapy. However, few studies were found to compare the effectiveness of PICC with peripheral intravenous access. The purpose of this study was to compare the effectiveness of intravenous therapy using peripheral intravenous access and PICC in hospitalized neonates. This study was a descriptive comparative. By using a purposive sampling technique, 32 neonates were involved as subjects of peripheral IV access group $(n=16)$ and PICC group $(n=16)$. Data were collected using observation forms for 24 hours within 5 days in a row. A Fisher Exact test was utilized to analyze the data. The results indicated that PICC was more effective than peripheral intravenous access $(\rho=0.00)$ in providing intravenous therapy for neonates. Accordingly, PICC is recommended for neonates requiring intravenous therapy in the hospital.
\end{abstract}

Key words: Intravenous therapy, neonates, peripheral intravenous access, Peripherally Inserted Central Catheter (PICC). 
Yani Setiasih: Perbandingan antara Akses Intravena Perifer dengan PICC

\section{Pendahuluan}

Tingginya Angka Kematian Bayi (AKB) pada periode neonatus menjadi permasalahan besar di Indonesia. Berdasarkan Riset Kesehatan Dasar tahun 2007 Penyebab kematian perinatal (0-7 hari) yang terbanyak adalah respiratory disorders $(35,9 \%)$ dan prematur $(32,3 \%)$, sedangkan untuk usia 7-28 hari penyebab kematian yang terbanyak adalah sepsis neonatorum $(20,5 \%)$ dan congenital malformations $(18,1 \%)$. Komplikasi yang menjadi penyebab kematian terbanyak adalah asfiksia, bayi berat lahir rendah, dan infeksi (Kemenkes RI, 2011). Jumlah neonatus yang meninggal di rumah sakit rujukan Jawa Barat pada tahun 2011 sebanyak 117 orang dari 3.876 neonatus (Dinas Kesehatan Provinsi Jawa Jawa Barat, 2011).

Berbagai macam masalah kesehatan pada periode neonatus dapat disebabkan oleh faktor ibu, faktor kondisi selama persalinan, dan faktor bayi itu sendiri (Halliday, McClure, \& Reid, 2001). Neonatus yang memiliki masalah kesehatan harus mendapatkan penanganan khusus di rumah sakit, disebabkan risiko kematian yang sangat tinggi, sehingga harus mendapatkan penanganan dan perlakuan ekstra khusus, cepat, tepat dan akurat.

Pemenuhan kebutuhan keseimbangan cairan dan elektrolit memegang peranan penting dalam penatalaksanaan awal pada pasien neonatus dalam kondisi sakit karena bayi biasanya dipuasakan dari nutrisi oral maupun enteral selama lima sampai tujuh hari terutama pada bayi dengan kondisi prematur. Hal ini mengakibatkan pemberianterapicairan dan elektrolit melalui intravena pada neonatus menjadi sangat penting untuk bertahan hidup (Cloherty, Eichenwald, \& Stark , 2010). Pemenuhan kebutuhan cairan dan elektrolit bertujuan untuk memenuhi kebutuhan cairan, kebutuhan elektrolit,kebutuhan nutrisi, dan farmakoterapi atau substansi terapeutik lain bagi neonatus (Wong, 2008).

Keberhasilan pemberian terapi intravena dipengaruhi oleh akses yang digunakan dalam terapi intravena yang telah diprogramkan. Oleh karena itu, pemasangan, pemantauan keefektifan, serta pemilihan akses intravena memiliki hubungan yang kuat dengan pemenuhan kebutuhan terapi intravena agar sesuai dengan kebutuhan neonatus, terutama neonatus dengan kondisi prematur yang memerlukan perawatan khusus dan dipuasakan dalam jangka waktu lebih dari lima hari.

Komplikasi atau kejadian yang tidak diharapkan dari pemasangan akses intravena perlu dipertimbangkan sebelum menentukan akses yang akan dipilih (Barria, Lorca \& Munoz, 2007). Moureau (2006) menyatakan bahwa kegagalan dalam mempertahankan kepatenan akses intravena menyebabkan terapi yang seharusnya diberikan kepada neonatus tertunda atau tidak dapat diberikan sepenuhnya sehingga dapat meningkatkan risiko kematian. Mempertahankan kepatenan akses intravena dalam waktu yang lama pada neonatus yang dirawat di rumah sakit memiliki tantangan tersendiri bagi perawat, mengingat karakteristik neonatus yang memiliki vena sangat kecil sehingga rentan berisiko tinggi terjadi plebitis. Rang (2003) dan Juffrie (2004) menyatakan bahwa kulit neonatus sangat rentan terhadap kerusakan jaringan karena strukturnya masih belum matang, sangat tipis, epidermis dan dermis tidak saling terkait atau longgar.

Peripherally inserted central catheter (PICC) merupakan salah satu peralatan terbaru yang telah diperkenalkan di Indonesia. Peripherally inserted central catheter digunakan untuk akses vena perifer, yang mempunyai beberapa kelebihan, yaitu dapat digunakan untuk pemberian makronutrisi yang mempunyai osmolaritas sangat tinggi $>900$ mOsm dan dapat digunakan dalam waktu yang cukup lama (21 hari-2 bulan) tergantung jenis kateter yang digunakan (Gomella, 2009). Namun demikian, beberapa penelitian seperti penelitian Galloway dan Bodenham (2004), Moureau (2005), Ohki, Yoshizawa, Watanabe, Kuwashima, dan Morikawa (2008), Paulson dan Miller (2008), serta penelitian Roy dan Lucille (2011) menyatakan bahwa PICC memiliki beberapa komplikasi yang dapat terjadi selama dan setelah dilakukan insersi pada bayi. Beberapa komplikasi tersebut meliputi oklusi, infeksi, trombosis, plebitis, edema, perdarahan berlebih pada area penusukan, dan malposisi atau pergeseran posisi kateter. Penggunaan PICC juga tidak menurunkan lama rawat (length of stay) di neonatal intensive care unit (NICU) walaupun dapat mengurangi 
Yani Setiasih: Perbandingan antara Akses Intravena Perifer dengan PICC

frekuensi penusukan vena. Komplikasi yang dapat muncul akibat penggunaan akses PICC dapat berpengaruh pada kelancaran masuknya cairan yang akan diberikan.

Penelitian-penelitian yang telah dilakukan sebelumnya menerangkan bahwa PICC terbukti efektif dalam pemberian terapi intravena (cairan, elektrolit, nutrisi parenteral dan farmakoterapi) dan juga dengan sejumlah komplikasi yang ditimbulkan, maka perlu dilihat efektifitas pemberian cairan yang telah diprogramkan pada pasien neonatus. Saat ini, belum ditemukan penelitian yang membandingkan pemberian terapi intravena melalui jalur perifer konvensional dengan akses perifer melalui PICC. Penelitian ini bertujuan untuk melihat perbandingan antara akses intravena perifer dengan PICC terhadap efektivitas pemberian terapi intravena pada neonatus.

\section{Metode Penelitian}

Penelitian ini bertujuan membandingkan akses intravena perifer dengan PICC terhadap efektivitas pemberian terapi intravena pada neonatus. Jenis penelitian ini adalah deskriptif komparatif. Responden dalam penelitian ini adalah neonatus yang lahir dengan usia kehamilan 37 minggu dan sedang terpasang akses intravena perifer atau terpasang akses intravena PICC. Neonatus yang mengalami plebitis, edema, infiltrasi, oklusi kateter, trombosis dan reaksi alergi pada saat awal observasi tidak dimasukkan sebagai responden. Penelitian ini melibatkan 32 orang neonatus yang didapat melalui teknik purposive sampling dan dibagi menjadi 2 kelompok. Kelompok A $(n=16)$ adalah neonatus yang mendapatkan terapi intravena melalui akses intravena perifer dan kelompok $\mathrm{B}(\mathrm{n}=16)$ adalah neonatus yang mendapatkan terapi intravena melalui PICC.

Efektivitas akses intravena dapat dilihat dari kesesuaian terapi intravena yang didapat neonatus dengan kebutuhan yang seharusnya didapatkan dalam 24 jam. Penelitian ini dilakukan selama lima hari dengan menggunakan lembar observasi. Jika seluruh terapi dapat diberikan dengan jumlah dan waktu pemberian yang tepat dan sesuai kebutuhan selama 24 jam maka akses intravena dikatakan efektif. Sebaliknya, jika keseluruhan terapi tidak dapat diberikan sesuai kebutuhan karena ketidakefektifan akses, maka akses intravena dikatakan tidak efektif.

Penelitian dilaksanakan di Rumah Sakit rujukan Jawa Barat. Analisis bivariat dilakukan menggunakan uji fisher exact dengan tingkat kepercayaan $95 \%$ dan nilai $\alpha=0.05$ yang diambil berdasarkan nilai signifikansi (nilai p) dan kemudian nilai tersebut dibandingkan dengan nilai alfa $\alpha$ (Gay, 2002 \& Schneider, dkk., 2005).

\section{Hasil Penelitian}

Karakteristik responden dari kelompok akses intravena perifer sebagian besar $(62,5 \%)$ berjenis kelamin perempuan. Median usia didalam kandungan pada kelompok ini adalah 31,50 minggu yang sebagian besarnya $(68,75 \%)>30$ minggu. Lebih dari setengah responden $(62,5 \%)$ pada kelompok ini termasuk dalam kelompok prematur sedang, dengan median berat badan 1.525 gram, serta dengan diagnosa preterm infant (PTI) sebanyak 31,25\%, PTI disertai Sepsis sebanyak 31,25\%, PTI disertai Respiratory Distress (RD) sebanyak 25\%, dan PTI disertai Necrotizing Entero Colotis (NEC) sebanyak $12,50 \%$.

Pada kelompok akses intravena yang menggunakan PICC memiliki perbandingan yang sama banyak antara jenis kelamin lakilakidanperempuan. Nilaimedian usia di dalam kandungan di kelompok ini adalah 30 minggu dimana sebagian besar $(62,5 \%)$ berusia $\leq 30$ minggu. Sebagian besar responden $(75,5 \%)$ termasuk dalam kelompok sangat prematur dengan median berat badan 1525 gram, serta dengan diagnosa PTI (12,5\%), PTI + Sepsis $(18,75 \%)$, PTI + RD $(68,75 \%)$.

Analisis bivariat didapatkan $\rho$ value $>0.05$ yang menunjukkan bahwa tidak terdapat perbedaan karakteristik responden kelompok PICC dan intravena perifer. Terapi intravena yang diberikan melalui akses intravena perifer, $31,3 \%$ responden pemenuhan kebutuhan terapi intravena tidak terpenuhi sejak hari pertama. Hari kedua dan ketiga meningkat menjadi $62,5 \%$ responden. Sampai pada hari terakhir observasi (5 
Yani Setiasih: Perbandingan antara Akses Intravena Perifer dengan PICC

hari setelah pemasangan), akses intravena perifer hanya dapat membantu memenuhi pemenuhan kebutuhan terapi intravena pada $12,5 \%$ responden. Sebaliknya, di kelompok dengan akses intravena menggunakan PICC menunjukkan bahwa kebutuhan terapi intravena dapat terpenuhi baik dari jumlah, dosis dan ketepatan waktu pemberiannya pada seluruh responden, mulai dari hari pertama setelah pemasangan sampai hari kelima observasi. Analisis bivariat menunjukkan terdapat perbedaan yang sangat signifikan ( $\rho$ value $=0.00)$ antara akses intravena perifer dengan PICC terhadap pemenuhan kebutuhan terapi intravena.

\section{Pembahasan}

Pemberian terapi intravena dilakukan pada neonatus baik dalam kondisi aterm maupun preterm. Hal ini sangat penting dilakukan untuk menyeimbangkan homeostasis tubuh terutama pada neonatus usia 5-6 haripostnatal (Cloherty, dkk., 2010). Penatalaksanaan terapi intravena ini dalam keperawatan bertujuan untuk memenuhi kebutuhan cairan, elektrolit, nutrisi parenteral, dan farmakoterapi atau substansi terapeutik lainnya pada neonatus. Terapi intravena diberikan berdasarkan pada kebutuhan, tujuan lamanya terapi, diagnosis pasien, usia, riwayat kesehatan, dan kondisi vena pada saat itu(Potter \& Perry, 2009). Peran perawat dalam pemberian terapi intravena ini bertujuan untuk mengidentifikasi jenis terapi intravena yang benar serta peralatan dan prosedur yang dibutuhkan

Menurut Gomella (2009), karekteristik pembuluh darah yang dimiliki bayi prematur memiliki elastisitas yang lebih rigid, sangat tipis, mudah pecah, permeabilitas kapilernya lebih tinggi, sehingga dapat lebih mudah untuk memungkinkannya terjadi shift cairan dari ruang intravaskuler menuju ke ruang ekstravaskuler. Letak pembuluh darah bayi yang prematur lebih dekat dan menempel di permukaan kulit, hal ini dapat memudahkan terjadinya kerusakan jaringan kulit yang parah (dapat sampai terjadinya nekrosis). Apabila akses kateter intravena tidak tepat berada di dalam lumen pembuluh darah maka dapat mengakibatkan zat-zat terapi intravena keluar dari intravaskuler menuju interstisial, terutama bila zat terapi intravena tersebut sangat iritan terhadap keutuhan jaringan kulit (Wong, 2008). Penentuan akses kateter intravena yang tepat pada neonatus perlu mempertimbangkan jenis-jenis farmakoterapi yang digunakan oleh neonatus serta diagnosis medis yang dapat dipengaruhi oleh diagnosis medis neonatus tersebut (Rang, 2003)

Keberhasilan dalam memenuhi kebutuhan terapi intravena neonatus sangat dipengaruhi oleh berbagai macam hal, salah satunya yaitu kepatenan akses kateter intravena. Kegagalan dalam mempertahankan kepatenan akses dari kateter intravena tersebut dapat menyebabkan terapi yang seharusnya diberikan kepada neonatus menjadi tertunda, tidak tepat waktu, atau tidak dapat diberikan sepenuhnya sesuai dengan kebutuhannya. Tanpa akses kateter intravena yang baik, pasien mungkin dapat mengalami proses penyembuhan yang lebih lambat lagi, sehingga lamanya perawatan di rumah sakit menjadi lebih lama (Moureau, 2006).

Pada penelitian ini menunjukkan bahwa neonatus yang telah dipasang akses kateter intravena perifer tidak mendapatkan terapi intravena perifer yang efektif, baik dari segi jumlah, dosis, maupun waktu pemberiannya. Pada hari pertama setelah pemasangan akses kateter intravena perifer terdapat responden yang mengalami masalah dalam kepatenan akses kateter intravena perifer. Pada hari kelima pemasangan kateter intravena perifer didapatkan data seluruh reponden diketahui tidak mendapatkan terapi kateter intravena perifer yang sesuai dengan kebutuhan yang seharusnya diterima oleh responden secara tepat dan akurat.

Pada hasil pengamatan sampai hari kelima, diperoleh data bahwa hanya $12,5 \%$ responden dari kelompok yang mendapatkan terapi antibiotik sesuai dosis dan waktu yang tepat dan tidak seorangpun yang mendapat terapi cairan elektrolit yang lengkap sesuai dengan kebutuhan per hariannya. Kegagalan pemenuhan terapi intravena pada kelompok ini terjadi dikarenakan adanya plebitis.

Plebitis merupakan terjadinya iritasi vena yang dapat disebabkan oleh trauma iritasi atau infeksi, yang ditandai dengan adanya bengkak, kemerahan, dan teraba hangat pada sisi insersi setelah 24-48 jam pertama setelah insersi (Moureau, 2006). Hal ini 
Yani Setiasih: Perbandingan antara Akses Intravena Perifer dengan PICC

dapat dicegah dengan cara memasukkan kateter intravena pada vena yang besar, lurus, dan terhindar dari tekukan yang menjadi tempat insersi, sehingga dapat mengurangi friksi pada lumen di dalam vena. Tindakan ini dilakukan dengan steril. Pemasangan akses kateter intravena perifer pada responden sudah dilakukan berdasarkan pada standar operasional prosedur (SOP) rumah sakit dan dilakukan oleh perawat profesional. Hasil penelitian ini dapat memperkuat penelitian yang dilakukan sebelumnya, bahwa risiko plebitis terjadi empat kali lebih tinggi pada saat menggunakan intravena perifer daripada PICC (Barria, dkk., 2007).

Peripherally inserted central catheter (PICC) lebih tepat dan efektif digunakan untuk memenuhi kebutuhan terapi intravena pada neonatus (Ohki, dkk., 2008; Paulson \& Miller, 2008; Powers \& Witschafter, 2010; \& Scales, 2005). Pendapat tersebut sesuai dengan hasil penelitian ini yang telah dibuktikan dari hasil pengamatan selama lima hari. Hasil penelitian ini menunjukkan bahwa terdapat $100 \%$ responden telah mendapatkan terapi intravena yang sudah sesuai dengan kebutuhan per hariannya. Hal ini dikarenakan PICC ditempatkan secara sentral, yang dapat menyebabkan konsentrasi cairan menjadi lebih tinggi sehingga dapat dimasukkan, begitu juga dengan pemberian nutrisi parenteral pada neonatus. PICC juga lebih aman digunakan untuk pemberian infus obat-obatan, karena PICC memiliki diameter yang lebih luas untuk digunakan pada vena dan dapat meningkatkan hemodilusi. Selain itu, PICC juga memiliki risiko sepsis minimal dibandingkan pemasangan kateter intravena perifer, karena jumlah insersi lebih sedikit sehingga kejadian port the entry (pintu masuk kuman) pun menjadi lebih sedikit apabila dibandingkan dengan pemasangan kateter intravena perifer (Moureau, 2005).

Cairan rumatan sangat dibutuhkan oleh neonatus untuk memelihara keseimbangan hemodinamik. Cairan rumatan yang memiliki kecukupan elektrolit esensial sangat penting dalam menunjang terjadinya keseimbangan cairan dan elektrolit pada kehidupan seharihari. Cairan rumatan ini digunakan pada saat proses metabolisme sel dalam menghasilkan energi, sehingga keseimbangan homeostasis di dalam tubuh selalu terjaga (Graber, 2002).
Padaneonatus, proporsicairan ekstraseluler terlihat lebih banyak apabila dibandingkan dengan cairan intraseluler, sehingga kecepatan metabolisme pada neonatus lebih cepat jika dibandingkan dengan orang dewasa. Hal ini mengakibatkan terbentuk banyak asam yang dapat mempercepat terjadinya asidosis. Asidosis juga dapat meningkatkan kebutuhan oksigen pada neonatus. Pada neonatus dengan kondisi prematur, hal ini dapat menyebabkan terjadinya henti napas. Selain itu, ginjal juga belum mampu mempertahankan cairan tubuh secara maksimal sehingga neonatus akan sangat rentan mengalami asidosis, dehidrasi, dan over hidrasi. Pencapaian keseimbangan cairan tersebut dapat dilakukan dengan cara pemberian cairan dan elektrolit yang efektif baik dilihat dari jumlah, kecepatan (pemberian cairan yang terlalu cepat dapat menyebabkan pirau dari kiri ke kanan melalui patent ductus arteriosus sehingga mudah terjadinya gagal jantung kongestif akibat beban berlebihan pada ventrikel), waktu pemberiannya harus tepat, serta memenuhi prinsip zero balance. Namun, jika akses intravena dalam pemberian terapi tidak adekuat maka zero balance sulit untuk dipertahankan seperti halnya yang terjadi pada kelompok responden dengan intavena perifer (Roy \& Lucille, 2011).

Menurut penelitian Cloherty, dkk. (2010), kemampuan pada neonatus dengan kondisi prematur belum adekuat untuk mencerna, mengabsorbsi, dan melakukan metabolisme zat-zat makanan melalui enteral, sehingga diperlukan juga nutrisi parenteral. Kecukupan jumlah kalori (terutama glukosa) sangat diperlukan bayi prematur untuk menghindari terjadinya katabolisme yang terus-menerus, sehingga untuk menghindari terjadinya hal tersebut, maka diperlukan pemenuhan nutrisi parenteral yang dilakukan secara tepat, adekuat, dan akurat baik dari segi jumlah maupun waktu pemberiannya. Hal ini akan tercapai apabila ditunjang oleh akses intravena yang memiliki kepatenan efektif, seperti pada akses PICC.

Bayi baru lahir terutama kondisi prematur memiliki respon kurang sensitif terhadap beberapa stimulus dari antigen yang disebabkan oleh belum sempurnanya pembentukan sistem pertahanan tubuh yang spesifik. Sistem imunitas dan kekebalan tubuh pada bayi prematur belum terbentuk 
Yani Setiasih: Perbandingan antara Akses Intravena Perifer dengan PICC

sempurna sehingga daya tahan tubuh terhadap infeksi sangat rentan. Oleh karena itu, bayi prematur dapat lebih mudah terkena infeksi. Apabila terkena infeksi biasanya tidaklah ringan sehingga sering jatuh dalam keadaan sepsis atau infeksi sistemik yang mengganggu ke seluruh tubuh (Nelson, 2006)

Penelitian ini menunjukkan hasil bahwa neonatus, terutama dengan kondisi prematur, akan lebih rentan mengalami kejadian infeksi, sehingga neonatus tersebut mendapatkan terapi antibiotik. Pada pemasangan akses kateter intravena perifer, kejadian plebitis sering sekali ditemukan akibat dari pembuluh darah bayi yang sangat tipis, permeabilitasnya tinggi, rapuh, dan lumennya sangat kecil (menurunkan hemodilusi) sehingga harus dilakukan penusukan yang berulang-ulang. Kondisi tersebut mengakibatkan port the entry (pintu masuk kuman) yang kemungkinan besar menyebabkan bayi mengalami sepsis.

Pemberian terapi antibiotik pada bayi perlu memperhatikan jumlah dosis dan ketepatan waktu pemberiannya. Sebagaimana yang kita ketahui bahwa terapi antibiotik mempunyai bioavailibilitas sendiri (waktu paruh bekerja efektif dalam membunuh kuman), dan apabila waktu pemberiannya kurang memperhatikan hal tersebut, dapat menyebabkan resistennya kuman terhadap antibiotik. Akses intravena yang efektif kepatenannya sangat diperlukan untuk mencegah kejadian tersebut.

\section{Simpulan}

Simpulan pada penelitian ini menunjukkan bahwa akses intravena dengan menggunakan PICC lebih efektif dalam pemenuhan terapi intravena apabila dibandingkan dengan akses kateter intravena perifer.

Penelitian ini menyarankan kepada pengambil kebijakan di rumah sakit untuk memprioritaskan pasien neonatus yang dirawat, baik di ruangan perawatan biasa maupun di ruangan perawatan intensif, supaya menggunakan PICC daripada akses intravena perifer dalam memenuhi kebutuhan terapi intravenanya. Penelitian selanjutnya dapat dikembangkan untuk melihat keefektifan PICC dalam membantu kesembuhan pasien dan pengaruhnya terhadap lama perawatan (lenght of stay) atau dapat melanjutkan penelitian ini untuk melihat keefektifan PICC dalam memenuhi kebutuhan terapi intravena pada neonatus dengan waktu observasi yang lebih lama serta jumlah responden yang lebih banyak.

\section{Daftar Pustaka}

Barria, R. M., Lorca, P., \& Munoz, S. (2007). Randomized controlled trial of vascular access in newborns in neonatal intensive care unit. JOGNN Clinical Research, 36(5), 450456.

Cloherty, J. P., Eichenwald, E. C., \& Stark, A. R. (2010). Manual of neonatal care. USA: Lippincott Williams \& Wilkins.

Dinas Kesehatan Provinsi Jawa Barat. (2011). Laporan rutin tahunan KIA 2010. Bandung: Dinas Kesehatan Provinsi Jawa Barat.

Gay \& Diehl. (2002). Research methods for business and management. USA: Macmillan Pub.Co.

Galloway, S. \& Bodenham, A. (2004). Longterm intravena access. British Journal of anesthesia, 92(5)

Gomella, T. L. (2009). Neonatology management, procedures, on-call problem, diseasses, and drugs (6th Ed.). North America: McGraw-Hill Companies.

Graber, M. A. (2002). Terapi cairan, elektrolit, dan metabolik. Jakarta: Farmedia.

Halliday, McClure, \& Reid L. (2001). Handbook of neonatal intensive care. London: Bailiere Tindall.

Juffrie, M. (2004). Penelitian kendali acak terbuka terhadap efektifitas dan keamanan cairan elektrolit rumatan pada neonatus dan anak. Sari Pediatri, 6(2), 91-96.

Kementerian Kesehatan RI. (2011). Laporan tahunan kemenkes 2011. Diakses dari http:// www.depkes.go.id/index.php/component/sea $\mathrm{rch} /$ ?searchword=aki+akb\&ordering=\&searc hphrase $=$ all. 
Yani Setiasih: Perbandingan antara Akses Intravena Perifer dengan PICC

Moureau, N. (2005). Neonatal/ pediatric peripherally inserted central catheter. UK: Vygon Corporation.

Moureau, N. (2006). Vascular safety: It's all about PICCs. Nursing management, 22-23.

Moureau, N. (2006). Vascular safety: It's all about PICCs. Nursing Management, 37(5), $22-27$.

Nelson, W. E. (2006). Nelson essentials of pediatrics:Infectionin theimunocompromised (5th ed.). Philadelphia: WB Saunder.

Ohki, Y., Yoshizawa, Y., Watanabe, M., Kuwashima, M., \& Morikawa, A. (2008). Complications of percutaneously inserted central venous catheters in japanes neonates. Japan Pediatric Society, 50, 636-639.

Potter, P. A. \& Perry, A. G. (2009). Fundamentals of nursing. Sydney: Mosby Elsevier.

Paulson, P. R., \& Miller, K. M. (2008). Neonatal peripherally inserted central catheters: recommendations for prevention of insertion and post insertion complications. Neonatal Network, 27(4), 245-257.

Powers, R. J. \& Wirtschafter, D. W. (2010). Decreasing central line associated bloodstream infection in Neonatal Intensive Care. Perinatology, 37, 247-272.

Rang, H.P., Dale, M.M., Ritter, J.M., Moore, P.K. (2003). Pharmacology (5th Ed). London: Churcill Livingstone

Roy, and Lucille. (2011). Percutaneous placement of central catheter. Neonatology, $1-4$.

Schneider, Z., Elliott, D., Beanland, C., Wood, G. L., \& Haber, J. (2005). Nursing research: Methods, critical appraisal and utilisation (2nd Ed.). Sydney: Mosby Elsevier.

Scales, K. (2005). Vascular acces: A guide to peripheral venous cannulation. Nursing Standar, 19(49), 48-52.

Wong, D. L. (2008). Pedoman klinis keperawatan pediatrik (4th Ed.). Jakarta: EGC. 